\title{
Demographic Profile, Knowledge, Attitude, and Practices of Blood Donors in a Low-Middle Income Country
}

\author{
Angelie Abegail Q. Naranja, Myra D. Oruga*®, Sheila R. Bonito \\ University of the Philippines Open University, Los Baños, Philippines
}

\begin{abstract}
Background: Demographic profile, knowledge, attitude and practices (KAP) of blood donors in a low-middle income setting was investigated in this study. The study determined the demographic profile of blood donors in terms of sex, age, ethnicity and level of education and measured the level of knowledge, attitude and practices in terms of blood donation.

Purpose: The relationship of the donor profiles in terms of level of knowledge, attitude and practices was also determined.

Methods: It utilized a cross-sectional study design which was conducted from February-October 2020. A self-administered questionnaire was distributed to the volunteers of blood donors of a non-institution-based blood bank establishment in Baguio City. Descriptive statistics and Chi-square were used to analyze the data. Ethical clearance was obtained and was approved.

Results: The results revealed that the majority of the respondents were female $(59.2 \%)$ with age ranged from $18-30$ years old $(75.3 \%)$ and in collegiate level (83.2\%). Majority of the respondents' ethnicities were Tagalog $(25.9 \%)$. Study revealed that respondents have a high level of knowledge in relation to blood donation, the attitude of the respondents revealed that blood donor had strong agreement to positive statements and disagreement to negative statements. Most of the respondents donated in the past, $62.3 \%$ are lapsed donors, $18 \%$ were first time donors and the majority had an intention to donate in the future.

Conclusion: In terms of relationship of Demographic Profile to KAP, only Practices revealed a significant relationship to sex, age, ethnicity and level of education with $\mathrm{P}$ value ranging from $0.05-<0.0001$.
\end{abstract}

\section{Jurnal Keperawatan Padjadjaran (JKP)}

Volume 9(2), 110-117 (C) The Author(s) 2021 http://dx.doi.org/10.24198/jkp v9i2.1658

\section{Article Info}

Received : Mei 12, 2021

Revised : July 12, 2021

Accepted : July 23, 2021

Published : August 31, 2021

Corresponding author

Myra D. Oruga

University of The Philippines Open University, Baños, Philippines,

4031, Phone: 6349 536-6001,

E-mail: myra.oruga@upou.edu.ph

\section{Citation}

Naranja, A. A. Q., Oruga, M. D. P., \& Bonito, S. R. (2021). Demographic Profile, Knowledge, Attitude, and Practices of Blood Donors in a Low-Middle Income Country. Jurnal Keperawatan Padjadjaran, 9(2), 114-117. https://doi.org/10.24198/jkp. v9i2.1658

\section{Website}

http://jkp.fkep.unpad.ac.id/index. $\mathrm{php} / \mathrm{jkp}$

This is an Open Access article distributed under the terms of the Creative Commons Attribution-NonCommercial 4.0 International License.

E-ISSN: 2442-7276 P-ISSN: 2338-5324
Keywords: Attitude; blood donors; knowledge; low-middle income country; practices

\section{Introduction}

Voluntary blood donation is the response to the demands of blood transfusion services in the healthcare system as recommended by international authorities; WHO, ISBT and Council of Europe. The sustainability and safety of national blood supplies rely on the recruitment and retention of nonremunerated blood donation and "low risk" donors instead of replacement and paid donors. By 2020 , WHO had a goal to eliminate paid donation and promote $100 \%$ voluntary and non-remunerated blood donation across the world. WHO global framework for action had recommended 20 strategies in its attempt to address the barriers on voluntary donation (WHO, 2010). A global effort was dedicated to formulating national blood systems among lowand middle-income countries (LMICs) to ensure the availability and safety of blood supply (Ifland, 2014). One of the WHO recommendations is the undertaking of knowledge, attitudes and practices in the local environment to understand the behaviors regarding blood donation and predict future blood donations (WHO, 2010).

Among LMICs, the access to safe blood products is lifesaving treatment and management of; congenital blood disorders, anemia caused by malaria, 
trauma, reduction of maternal mortality from complications such as hemorrhage during childbirth and road traffic accidents (WHO, 2010). However, recruitment of low-risk donors in developing countries is a challenging feat. In sub-Saharan Africa (SSA) and in the South East Asia region (SEAR), there is still prevalence of replacement of blood by family and friends which have higher risk for blood borne infections and paid donor system.

The problem of decreasing frequency of blood donors impact the availability of blood which may be due to the following prevailing misinformation, low awareness and poor knowledge, unfavorable attitude regarding blood donation, low practice mainly due to the lack and accessibility of infrastructure (Melku et al., 2018; W. Tadesse, Ayalew, Yisma, Liben, \& Wudu, 2018), time constraints from work and studies, paperwork, questioning, eligibility requirements (Charbonneau, Cloutier, \& Carrier, 2016), failure to make positive attitudes to actual blood donation (Lownik et al., 2012; van Dongen, 2015) and the advent of increasing understanding of blood transmissible diseases resulted to a stricter deferral criteria which the current pool of blood donors (Schnaubelt \& Nadder, 2010).

The blood collection centers must regularly monitor the patterns of blood donors and donation behaviors to be able to direct their donor management practices (Veldhuizen, 2013). Unfortunately, lapses in blood donation happen after the fifth donation. Lapsing donors are those who "donated at least once within the last 24 months, but not in the last 12 months" (Veldhuizen, 2013). Lapses happen due to changes in residency, lifestyle-related deferral, the lack of personal request to donate (Misje, Bosnes, \& Heier, 2008), physical reaction and busy lifestyle (van Dongen, 2013), and medical deferral reasons (Moog, 2009).

This study focused on donor retention, defined by European blood services providers as the prevention of donors from lapsing from donating blood and becoming inactive. The goal among blood establishments is that first time donors would become regular donors. Regular donors are "those who made at least two donations within the last 24 months". Regular donors can ensure the adequate blood supply in the future while also participating to motivate other people to donate blood. Hence, KAP survey among the current donors may fill in the knowledge gap on how to convert them as committed blood donors (Ringwald, Zimmermann, \& Eckstein, 2010)

There are still gaps on data regarding 1) donor retention 2) lack of focus among first time, repeat and lapsed donors, 3) most of the samples were college undergraduates thus the results may not be generalizable (Godin, Vézina-Im, BélangerGravel, \& Amireault, 2012; Bagot, Murray \& Masser, 2016; van Dongen, 2015). The findings of the research is useful in understanding the donors to be able to formulate a responsive donor recruitment and retention strategy and long term donor management
(Satake, 2016; Veldhuizen, Doggen, Atsma, \& Kort, 2009; World Health Organization, 2017).

In response to global guidelines on the provision of blood, the Philippine government has enacted Republic Act no. 7719, National Blood Services Act of 1994 which implements the National Voluntary Blood Services Program which promotes voluntary blood donation to meet the needs of Filipino patients for available and safe blood products (Republic Act No. 7719, 1994). Despite the organization of blood donation programs among developing countries, there are still shortages of blood products.

Baguio City is an urbanized city in the middle of the mountain ranges of Cordillera Administrative Region (CAR), which is $240 \mathrm{~km}$ away from Manila, the capital of the Philippines. It is the center of commerce, tourism and education within the region (Estoque \& Murayama, 2011). As of the 2015 census of Philippine Statistics Authority, 345,000 is the estimated population in the city (PSA, 2010; n.d., 1994). Based on the census in 2010 , it is shown that $51.2 \%$ of the population are female and $48.8 \%$ comprise the males. The median age of the population is 24.4 years (Philippine Statistics Authority (PSA), 2010; n.d., 1994). Baguio City's population consists of different native groups which are Igorots, llocano, Pangasinenses, Tagalogs and Kapampangans (Estoque \& Murayama, 2011) According to the Philippine Red Cross (PRC)-Baguio City Chapter data in 2018, 6812 of the population has been the donors which is only about $2 \%$ of the population (PRC, 2017).

It is problematic to generalize the results from other blood donor studies because the city has a unique demographic pattern which consists of young people and changes are influenced by the city's rapid urbanization (Estoque \& Murayama, 2011). Change in the environmental landscape affects the maintenance of the donor blood pool (Unnikrishnan et al., 2011). Young and female donors have increased chances of lapsing in blood donation (van Dongen, 2015) which is usually the case in the city of Baguio. Another problem which contributes to challenges in donor selection is the increasing number of HIV cases in the city, as of 1984 to January 2018 with 281 cases (Department of Health, 2018) thus, the need for retaining healthy blood donors. Studying the knowledge, attitude and practice of regular and lapsed donors would give an overview about the current donors of the city that can assist in filling the gaps in terms of donor profiles information. Hence, it can assist in formulating appropriate strategies to ensure the adequate blood supply in the city. This study determines the following: The profile of blood donors in Baguio City in terms of sex, age, ethnicity, level of education in Baguio City; the level of the knowledge of blood donors in terms of blood donation; the attitudes of blood donor respondents in terms of blood donation and the practices of blood donor respondents in terms of blood donation.

Knowledge, attitude and practice (KAP) 
research is recommended by WHO (2010) to produce essential data for demonstrating present donor recruitment and retention strategies. The study is important among Blood Bank Institutions since the result would serve as a base-line data and identification of behavioral patterns useful in crafting health communication strategies. Policy makers may utilize this evidence-based research in blood donation policy development.

The research's respondents are from PRCBaguio City data base. The KAP Survey was conducted from February to October 2020.

\section{Methods}

The study utilized a cross-sectional study design, conducted from February -October 2020. A selfadministered questionnaire was distributed to the volunteering blood donors of 17-70 years old at a non-institution-based blood collection establishment in Baguio City after a successful blood donation. The data was collected through a validated and pretested questionnaire. It was analyzed using SPSS and presented using tables. Ethical clearance was obtained from the SLU Research Ethics Committee See. The estimated population size in 2019 was 1,793. The sample size was calculated using Epi info version 7.2 .2 .2 , at $95 \%$ confidence interval which was 316 . The study was conducted at Philippine Red Cross (PRC)-Baguio City Chapter in Baguio City, Benguet Province, Philippines. It is a non-institution-based blood service facility that provides the following programs; donor recruitment and retention, blood collection, blood component processing and blood storage and issuance. The selfadministered guided questionnaire was prepared in English and Filipino. The data collection instrument was adapted from the studies of Gebresilase, Fite, \& Abeya (2017), Melku et al (2018) and Das et al (2014) for evaluating KAP of blood donors and the tool was designed to collect donor demographic profile (sex, age, ethnicity, level of education), level of knowledge, attitude and practices. The questionnaire was pre-tested and validated before data collection, reliability and validity were carried out. Data was coded, checked, and analyzed in SPSS version 20.0. Appropriate inferential and descriptive statistics were used to process the data. Percentages were used to analyze the profile of blood donors and level of knowledge. The Attitude of blood donors were analyzed through mean and standard deviation. The relationship of knowledge, attitude and practices with the demographic profiles were calculated using Chi-square with the

Table 1. The Profile of Blood Donors in Baguio City $(n=316)$

\begin{tabular}{|c|c|c|}
\hline $\begin{array}{c}\text { Profile of Blood } \\
\text { Donors }\end{array}$ & Categories & $\%$ \\
\hline \multirow[t]{2}{*}{ Sex } & Male & 40.8 \\
\hline & Female & 59.2 \\
\hline \multirow[t]{4}{*}{ Age (Year) } & $18-30$ years old & 75.3 \\
\hline & $31-40$ years old & 10.4 \\
\hline & $41-50$ years old & 8.5 \\
\hline & Above 50 years old & 5.7 \\
\hline \multirow[t]{5}{*}{ Education } & Elementary & 3.5 \\
\hline & High school & 8.2 \\
\hline & Senior high level and Technical Vocation & 3.8 \\
\hline & College level & 83.2 \\
\hline & Masters and PhD & 1.6 \\
\hline \multirow[t]{10}{*}{ Ethnicity } & Igorot & 14.2 \\
\hline & Ifugao & 2.2 \\
\hline & Kalinga & 3.2 \\
\hline & Kankana-eys & 14.2 \\
\hline & Ibaloi & 5.4 \\
\hline & Ilocano & 24.4 \\
\hline & Pangasinense & 3.8 \\
\hline & Tagalog & 25.9 \\
\hline & Kapampangan & 2.8 \\
\hline & Others & 3.8 \\
\hline \multirow[t]{3}{*}{ Donation Status } & First time donor & 18 \\
\hline & Lapsed donor & 62.3 \\
\hline & Regular donor & 19.6 \\
\hline
\end{tabular}


significance level at $p$ value $<0.05$. The results were presented in texts and tables.

\section{Results}

\section{Profile of Blood Donors in Baguio City}

Profile of blood donors in Baguio City based on sex, age (year), education, ethnicity and donation status were summarized in Table 1. Among the 316 blood donor respondents, the majority of blood donors were women $(59.2 \%)$, the highest donation rate was from the age group of $18-30$ years $(75.3 \%)$ from the group of college level education (83.2\%). Based on ethnicity, $25.9 \%$ were Tagalogs, $24.4 \%$ were llocanos, $14.2 \%$ were Igorots and Kankana-eys.

\section{Attitude of Blood Donors in Relation to Blood Donation}

Attitude of blood donors in relation to blood donation is shown in Table 3. The questions in relation to attitude towards blood donation included five positive and five negative attitude statements. The questions were based on altruism, willingness to be a voluntary and regular donor, receiving incentives for donation and blood donation experience. The blood donor respondents exhibited strong agreement to positive attitude statements which are the following: young people should donate more frequently compared to old people, the best way to donate is through voluntary donation, willingness to become a regular donor and donating blood is a good experience, agreeing that donating blood is one self's moral duty. While the blood respondents disagreed among the negative attitude statements; people who donate blood should receive something in exchange, donors are temporarily weakened, donors can contract diseases, donating done to get free screening tests and the best way to donate is at the request of relatives. The blood donor respondents showed a favorable attitude.

\section{Practices of Blood Donors in Relation to Blood Donation}

Practices of Blood Donors in Relation to Blood Donation were measured through the history of donation, intention to donate in the future and donation status (first time, regular and lapsed donor). Results in Table 4 revealed that for the history of donation, $29.4 \%$ (57) donated more than three times, $27.8 \%$ (88) donated two to three times, $24.7 \%$ (78) donated once and 18\% (57) had never donated before. The results on intention to donate in the future showed that $34.8 \%$ of the respondents intended to donate every 3 months, $25.6 \%$ intended to donate every 6 months while $7.3 \%$ would only donate when asked for. According to the responses

Table 2. Level of Knowledge of Blood Donors on Blood Donation

\begin{tabular}{lcc}
\hline \multicolumn{1}{c}{ Knowledge } & Correct Response (\%) & Interpretation \\
\hline Donor Eligibility & $76.90-95.90$ & Very High \\
Blood Typing & $74.40-91.90$ & Very High \\
Blood Testing & $78.80-94.90$ & Very High \\
Mean & 84.40 & Very high \\
\hline
\end{tabular}

Table 3. Attitude of Blood Donors in Relation to Blood Donation

\begin{tabular}{|c|c|c|c|}
\hline Attitude of Blood Donors & Mean & Std. Deviation & Interpretation \\
\hline \multicolumn{4}{|l|}{ Positive Attitude on Blood Donation } \\
\hline I donate blood because it is my moral duty. & 3.1013 & 0.79833 & Agree \\
\hline $\begin{array}{l}\text { I think people who donate blood should receive } \\
\text { something in exchange }\end{array}$ & 1.8196 & 0.74048 & Disagree \\
\hline $\begin{array}{l}\text { I think people who donate blood are temporarily } \\
\text { weakened }\end{array}$ & 2.1709 & 0.59301 & Disagree \\
\hline $\begin{array}{l}\text { I think young people should frequently donate blood } \\
\text { compared to old people }\end{array}$ & 3.3133 & 0.80865 & Strongly Agree \\
\hline $\begin{array}{l}\text { I think the best way to donate blood is through } \\
\text { voluntary donation }\end{array}$ & 3.7057 & 0.54519 & Strongly Agree \\
\hline \multicolumn{4}{|l|}{ Negative Attitude on Blood Donation } \\
\hline I think people who donate can contract diseases & 2.0411 & 0.49269 & Disagree \\
\hline I donate blood to get free screening tests & 1.962 & 0.75075 & Disagree \\
\hline I am willing to become a regular donor & 3.7057 & 0.52138 & Strongly Agree \\
\hline $\begin{array}{l}\text { In my opinion the best way to donate blood is at the } \\
\text { request of relatives }\end{array}$ & 2.0538 & 0.50422 & Disagree \\
\hline I think donating blood is a good experience & 3.8196 & 0.45327 & Strongly Agree \\
\hline
\end{tabular}


Table 4. Practices of Blood Donors in Relation to Blood Donation

\begin{tabular}{lcc}
\hline \multicolumn{1}{c}{ History of blood donation } & $\mathbf{n}$ & $\%$ \\
\hline Never donated & 57 & 18 \\
Donated Once & 78 & 24.7 \\
2-3 Times & 88 & 27.8 \\
More than 3 times & 93 & 29.4 \\
How often do you intend to donate? & 110 & 34.8 \\
Every 3 months & 81 & 25.6 \\
Every 6 months & 42 & 13.3 \\
Once a year & 23 & 7.3 \\
Only when asked for & 60 & 19 \\
N/A & & 18 \\
Donation Status & 57 & 19.6 \\
First time donor (No history of donation) & 62 & 62.3 \\
Regular donor (Donated blood twice within the last 2 years) & 197 & \\
Lapsed Donor (Donated at least once within the last 24 months, but did not donate & & \\
in the last 12 months) & & \\
\hline
\end{tabular}

on donation status, $62.3 \%$ were lapsed donors, $19.6 \%$ were regular donors and $18 \%$ were first time blood donors. The study also revealed that most of the respondents have a previous history of donation, only $18 \%$ had not donated in the past or first-time donors while the majority were lapsed donors.

Relationship of Demographic Profile of Blood Donors to Knowledge, Attitude and Practices on Blood Donation

Relationship of Demographic Profile of Blood Donors to Knowledge, Attitude and Practices on Blood Donation were analyzed using Chi square test of association at $P$ value $=0.05$ level of significance (Table 5). Results revealed that Practices of Blood Donors in terms of History of Blood donation ( $P$ value $=<0.001)$ Frequency of future blood donation $(\mathrm{P}$ value $=.001)$ and Donation Status $(\mathrm{P}$ value $=$ $<0.001$ ) has significant relationship to sex of blood donors. Frequency of future blood donation has significant relationship to Age of the blood donors ( $P$ value $=0.016$ ), Ethnicity has significant relationship to Donation status of blood donors ( $P$ value $=0.006$ ) and Level of Education has significant relationship to History of blood donation ( $P$ value $=0.050$ ). Knowledge and Attitude shows no significant relationship to the Demographic profile of the blood donors.

\section{Discussion}

The demographic profile was similar to the changing demographic landscape of Baguio City as reflected in the 2015 Census where the number of women was slightly higher than men, the median age in the city was young individuals around 24 years old who were college students and the major ethnicities were represented in the study (Estoque \& Murayama, 2011). In contrast to the Global Status Report on
Blood Safety and Availability by WHO (2017), a survey from 118 countries showed otherwise- only $30 \%$ were the female donors wherein the lowest donation rate of female donors was in the Eastern Mediterranean region and the highest number of female donors was in the America and second was the South East Asia (WHO, 2017), the same is true with the studies of Veldhuizen et. al (2009). The same report noted that among developing countries, the age group of donors were below 18 years old while 18-24 years old were the age group that usually donated among high income and upper middle-income countries. Globally, especially in developing countries, young people account for the majority of the blood donors (WHO, 2017). Over the course of the study, the ethnic groups that were recorded were the following; lgorot, Ifugao, Kalinga, Kankana-eys, Ibaloi, Ilocano, Pangasinense, Tagalog, Kapampangans, Bisaya, Bontoc, Bicolano, Cagayanon, Applai, Indian, Ibaneg, Chinese and Isneg. The ethnicities reflected the rich cultural diversity in the city. These diverse groups were an assembly of potential new donors who can be converted to regular donors. On the downside, the under-represented groups may require rare blood types which may not be found among the blood banks in the city. Recruitment and retention from minor ethnic group blood donors is still a challenge among blood donation facilities in Australia, Canada, Europe and the United States (Blacks and Hispanics) (van Dongen, Mews, Kort, \& Wagenmans, 2016; Patel et al., 2019).

Level of Knowledge of Blood Donors on Blood Donation in this research revealed a very high knowledge which was the same with the study done by Lownik et al. (2012). Lownik et al. (2012) summarized $18 \mathrm{KAP}$ studies from developing countries, the countries showed commendable level of knowledge regarding the blood uses, testing the 
Table 5. Relationship of Demographic Profile of Blood Donors to Knowledge, Attitude and Practices on Blood Donation

\begin{tabular}{lcccccc}
\hline Variable & $\begin{array}{c}\text { Knowledge } \\
\text { (P value) }\end{array}$ & $\begin{array}{c}\text { Positive } \\
\text { attitude } \\
\text { (P value) }\end{array}$ & $\begin{array}{c}\text { Negative } \\
\text { attitude } \\
\text { (P value) }\end{array}$ & $\begin{array}{c}\text { History } \\
\text { of blood } \\
\text { donation } \\
\text { (P value) }\end{array}$ & $\begin{array}{c}\text { Frequency of } \\
\text { future blood } \\
\text { donation } \\
\text { (P value) }\end{array}$ & $\begin{array}{c}\text { Donation } \\
\text { Status } \\
(\mathbf{P} \text { value) }\end{array}$ \\
\hline Sex & 0.334 & 0.810 & 0.113 & $<0.001$ & $<0.001$ \\
\hline Age & 0.247 & 0.225 & 0.954 & 0.299 & 0.016 & 0.267 \\
\hline Ethnicity & 0.431 & 0.091 & 0.577 & 0.798 & 0.676 \\
\hline Level of & 0.302 & 0.927 & 0.567 & 0.050 & 0.463 \\
\hline Education & & & & & 0.156 \\
\hline
\end{tabular}

$P$ value $=0.05$ level of significance

types of donors however low the knowledge on the requirements to be an eligible donor is. The respondents of the current study were already donors which would have contributed to a high level of knowledge. Among the questions in the current study, the common misconception is that blood could not transmit infections which is in contrast to the results of KAP studies in developing countries showing that respondents are fearing the risk of contracting infections (Lownik et al., 2012) Based on five KAP studies targeting university students, the systemic review showed high awareness based on their overall scores in the assessment (De Los Santos \& Firmo, 2019). This is very promising because good knowledge increases the willingness to be a regular donor (Lownik et al., 2012).

The favorable attitude on blood donation is a common result of KAP studies from developing countries and there is no study yet that recorded a negative attitude on blood donation. However, certain populations from Tanzania, Nigeria, Bangladesh, and South Africa are not willing to donate (Lownik et al., 2012). On Attitude of Blood Donors, in the systematic review of De Los Santos and Firmo (2019), most university students of five research studies have favorable attitudes regarding blood donation. The literature agrees that university students affirm that blood donation is an act in helping others, it must be voluntary, incentives and rewards are unnecessary, and there is willingness to be donors also in medical emergencies. The favorable result of prevalent positive attitude increases the likelihood of first-time donors returning.

Furthermore, the same study showed in terms of practices. The factors which increased the likelihood of first-time donors to donate again were favorable attitude, donation as being under a person's control, importance placed on being a blood donor and confidence in the ability to donate despite being given incentives (Bagot, Murray \& Masser, 2016). The most common deterrent to blood donation among developing countries was fear; fear of pain (China), fear of needles (Thailand, Bangladesh and Trinidad and Tobago) and fear of being infected with HIV (Nigeria and Tanzania), infertility and hepatitis (Iran) (Lownik et al., 2012). Based on the 18 KAP studies from developing countries, the number of previous donors varies depending on their target population. KAP studies from Brazil, Burkina Faso, Nigeria targeted previous blood donors. While in studies which targeted the general population, the percentages showed the blood donors who donated in the past; China (27.6\%), Iran (37.9\%), Haiti (6.1\%) and Molva (42\%) (Lownik et al., 2012). WHO (2017) recorded that Europe had 85\% repeat voluntary donors while Western Pacific had $48 \%$ and South East Asia had $47 \%$ while the lowest recorded were in the Americas (19\%). De Los Santos and Firmo (2019) reviewed five KAP studies in relation to university students, results noted low actual donation among university students. The results were encouraging because they were intending to practice blood donation in the near future despite the current Covid-19 pandemic situation. Though they intend to donate every 3 months or annually, this result intensifies the need for strategies on retaining these donors and converting the first-time donors to become regular donors. In the context of donor retention, van Dongen (2015) states that females, young people and minorities are prone to lapse in blood donation, this may explain the high number of lapsed donations in the city since university students who were blood donors may not donate again because of the following reasons; contacting them is difficult, students who donated due to peer pressure have lower chances on donating again once they have been removed from that environment and mobile blood drives among schools may be crowded which increases the chances of adverse reactions such as fainting and nausea which decreases the willingness to donate (Lownik et al., 2012). Furthermore, reasons for lapsing may be due to changes in residency of college students after graduation, no one is asking them to donate, lifestyle-related and medical reasons (Misje, Bosnes, \& Heier, 2008; Moog, 2009; van Dongen, 2013).

On the Relationship of the Profile of the Blood Donors to the KAP on Blood Donation, this research revealed that only practices revealed a significant relationship with gender, age, ethnicity and level of education, neither knowledge and attitude showed the same relationship. 


\section{Conclusion}

The results in the demographic profile of blood donor respondents are similar to the unique demographic landscape in Baguio City. The majority was women $(59.2 \%)$, the highest donation rate was from the 1830 years old age group $(75.3 \%)$ and college level educated $(83.2 \%)$. Based on ethnicity, $25.9 \%$ were Tagalogs, $24.4 \%$ were llocanos, $14.2 \%$ were Igorots and Kankana-eys. The blood donor respondents had a very high level of knowledge on most facts about blood donation, donor eligibility, blood typing and testing. The blood donor respondents had a favorable attitude on statements regarding altruism, willingness to be a volunteer and regular donor, receiving incentives for donation and blood donation experience. For practices, the history of blood donation revealed that the majority of donors have donated before and only $18 \%$ are first-time donors. The majority of them showed intention to donate in the future and the majority are lapsed blood donors. Sustaining the availability of safe blood supply is of utmost importance especially during pressures of rapid urbanization in the city and social pressures exacerbated by the COVID-19. Though the results of the KAP survey may vary based on context, the results showed increased intention to donate in the future as reflected in the knowledge, attitude and practices. Therefore, this reveals that retaining this donor pool using retention strategies is actually a need right now as a response to the fluctuating blood supply. The results of the survey could be used by blood bank facilities in crafting targeted retention strategies to build a safe and reliable blood system. Practices revealed a significant relationship with gender, age, ethnicity and level of education, neither Knowledge and Attitude showed the same relationship.

\section{Recommendations}

Design a communication strategy campaign based on the current profile of blood donors in the city (use of specific dialects) to widen the reach of potential donors in order to convert negative attitude on blood donation to positive attitude; Collaborations with the local government units, public and private organization are needed to maintain a stream of blood donations and offer this evidence-based research in crafting donor retention program policy; Explore the other facets of retention strategies in Baguio City such as studying medical deferral, anxiety and stress, failing to plan for donation as barriers of retaining donors may be studied further; Explore the use of electronic communication and telecommunication models to help track blood donors and achieve retention strategies; Consider and explore other profile in associating KAP such as income and marital status.

\section{References}

Bagot, K. L., Murray, A. L., \& Masser, B. M. (2016). How can we improve retention of the first-time donor? A systematic review of the current evidence. Transfusion Medicine Reviews, 30(2), 81-91. https://doi.org/10.1016/j. tmrv.2016.02.002

Bharucha, Z. S. (2005). Donor management in the South-East Asia region (SEAR). Developments in Biologicals, 120, 145-153. https://europepmc.org/article/med/16050168

Charbonneau, J., Cloutier, M.-S., \& Carrier, É. (2016). Why do blood donors lapse or reduce their donation's frequency?. Transfusion Medicine Reviews, 30(1), 1-5. https://doi. org/10.1016/j.tmrv.2015.12.001

Das, K., Kalyan, G., Sachdev, S., Kaur, B., Singh, C., \& Nongbri, D. (2014). Knowledge, attitude and practices of blood donors toward blood donation. Journal of Postgraduate Medicine Education and Research, 48, 123-127. https:// doi.org/10.1155/2013/797830

de Los Santos, J. (2019). Knowledge, attitude and practice on blood donation among university students: A systematic review of literature. https://dx.doi.org/10.7759\%2Fcureus. 7733

Department of Health. (2018). HIVIAIDS cases in cordillera administrative region (CAR). http:// caro.doh.gov.ph/wp-content/uploads/2018/04/ HIV-AIDS-Cases-in-CAR.pdf

Estoque, R., \& Murayama, Y. (2011). City Profile: Baguio. Cities, 30, 240-251. https://doi. org/10.1016/j.cities.2011.05.002

Gebrselassie, H.W., Fite, R.O., \& Abeya, S.G. (2017). Knowledge, attitude and practice of students towards blood donation in Arsi university and Adama science and technology university: A comparative cross-sectional study. BMC Hematology, 17. https://doi. org/10.1186/s12878-017-0092-x

Godin, G., Vézina-Im, L.-A., Bélanger-Gravel, A., \& Amireault, S. (2012). Efficacy of interventions promoting blood donation: A systematic review. Transfusion Medicine Reviews, 26(3), 224-237. https://doi.org/10.1016/j.tmrv.2011.10.001

Ifland L. (2014). Promoting national blood systems in developing countries. Current opinion in hematology, 21(6), 497-502. https://doi. org/10.1097/MOH.0000000000000078

Lownik, E., Riley, E., Konstenius, T., Riley, W., \& McCullough, J. (2012). Knowledge, attitudes and practices surveys of blood donation in developing countries. Vox Sanguinis, 103(1), 64-74. https://doi.org/10.1111/j.14230410.2012.01600.x

Melku, M., Asrie, F., Shiferaw, E., Woldu, B., Yihunew, Y., Asmelash, D., \& Enawgaw, B. (2018). Knowledge, attitude and practice regarding blood donation among graduating undergraduate health science students at the University of Gondar, Northwest Ethiopia. 
Ethiopian Journal of Health Sciences, 28(5), 571-582. https://doi.org/10.4314/ejhs.v28i5.8

Misje, A.H., Bosnes, V., \& Heier, H.E. (2008). Recruiting and retaining young people as voluntary blood donors. Vox Sanguinis, 94(2), 119-124. https://doi.org/10.1111/j.14230410.2007.01004.x

Moog, R. (2009). Retention of prospective donors: A survey about services at a blood donation centre. Transfusion and Apheresis Science: Official Journal of the World Apheresis Association: Official Journal of the European Society for Haemapheresis, 40(3), 149-152. https://doi.org/10.1016/j.transci.2009.03.002

National Blood Services Act of 1994, Republic Act No. 7719, (1994). Retrieved December 12, 2020, from https://www.officialgazette.gov. ph/1994/05/05/republic-act-no-7719/

Patel, E.U., Bloch, E.M., Grabowski, M.K., Goel, R., Lokhandwala, P.M., Brunker, P.A.R., ... Tobian, A.A.R. (2019). Sociodemographic and behavioral characteristics associated with blood donation in the United States: A population-based study. Transfusion, 59(9):2899-2907. https://doi.org/10.1111/ trf. 15415

Philippine Red Cross (PRC). (2017). Blood donation Census in Philippine National Red CrossBaguio Chapter. Retrieved December 18, 2020, from https://redcross.org.ph

Philippine Statistics Authority (PSA). (2013, July 12). Population of 319 thousand was Recorded in Baguio City (Results from the 2010 Census of Population and Housing). Philippine Statistics Authority. Retrieved December 12, 2020, from https://psa.gov.ph/content/population-319thousand-was-recorded-baguio-city-results2010-census-population-and-housing

Republic Act No. 7719, 1994. An Act Promoting Voluntary Blood Donation, Providing For An Adequate Supply Of Safe Blood, Regulating Blood Banks, And Providing Penalties For Violation Thereof (1994). Retrieved December 12, 2020, from https://doh.gov.ph/blooddonation-program\#: : text=Republic $\% 20$ Act $\% 20$ No.,donation $\% 20$ is $\% 20$ a $\% 20$ humanitarian\%20act

Ringwald, J., Zimmermann, R., \& Eckstein, R. (2010). Keys to open the door for blood donors to return. Transfusion Medicine Reviews, 24(4), 295-304. https://doi.org/10.1016/j. tmrv.2010.05.004

Satake, M. (2016). Planning donor recruitment strategies with an eye on the future. ISBT Science Series, 11(S2), 37-40. https://doi. org/10.1111/tme.12275

Schnaubelt, A., \& Nadder, T. (2010). Factors influencing a military blood donor's intention to donate: an application of the theory of planned behavior. [Doctoral's dissertation, Virginia
Commonwealth University]. VCU Scholar Compass. Retrieved January 12, 2021 from https://doi.org/10.25772/0ZZO-N362

Tadesse, T., Berhane, T., Abraha, T. H., Gidey, B., Hagos, E., Grum, T., \& Gerensea, H. (2018). Blood donation practice and associated factors among health professionals in Tigray regional state public hospitals, northern Ethiopia. BMC Research Notes, 11(1), 677. https://doi. org/10.1186/s13104-018-3786-7

Tadesse, W., Ayalew, Y., Yisma, E., Liben, M. L., \& Wudu, M. (2018). Knowledge, attitude, practice and associated factors towards voluntary blood donation among regular health science students of Samara University, Ethiopia. Health Science Journal, 12(1). https://doi. org/10.21767/1791-809X.1000542

Unnikrishnan, B., Rao, P., Kumar, N., Ganti, S., Prasad, R., Amarnath, A., ... Aggarwal, P. (2011). Profile of blood donors and reasons for deferral in coastal South India. The Australasian Medical Journal, 4(7), 379-385. https://doi.org/10.4066/amj.2011.641

van Dongen, A. (2015). Easy come, easy go. Retention of blood donors. Transfusion Medicine (Oxford, England), 25(4), 227-233. https://doi.org/10.1111/tme.12249

van Dongen, A., Mews, M., Kort, W., \& Wagenmans, E. (2016). Missing minorities-a survey based description of the current state of minority blood donor recruitment across 23 countries. Diversity and Equality in Health and Care, 13(1), 138-145. https://doi.org/10.21767/20495471.100042

van Dongen, A. (2013). Retention of new blood donors: Implications for interventions [Master's thesis, Maastricht University]. Maastricht University. Retrieved January 02, 2021, from https://cris.maastrichtuniversity.nl/ws/ portalfiles/portal/907952/guid-d718de0d-6ef94132-8db4-b765464367ec-ASSET1.0.pdf

Veldhuizen, I. (2013). Blood donor profiling using donation patterns. ISBT Science Series, 8. https://doi.org/10.1111/voxs.12017

Veldhuizen, I.J., Doggen, C.J., Atsma, F., \& De Kort, W.L. (2009). Donor profiles: demographic factors and their influence on the donor career. Vox sanguinis, 97(2), 129-138. https://doi. org/10.1111/j.1423-0410.2009.01201.x

World Health Organization [WHO]. (2010). Towards $100 \%$ voluntary blood donation: A global framework for action. Retrieved December 03, 2020, from https://www.who.int/publications/i/ item/towards-100-voluntary-blood-donation-aglobal-framework-for-action

World Health Organization [WHO]. Global Status Report on Blood Safety and Availability. (2017). Retrieved December 03, 2020, from https://apps.who.int/iris/bitstream/hand le/10665/254987/9789241565431-eng.pdf 